\title{
Leptin Receptor as a Potential Target to Inhibit Human Testicular Seminoma Growth
}

Salvatore Panza, ${ }^{*}$ Luca Gelsomino, ${ }^{*}$ Rocco Malivindi, ${ }^{*}$ Vittoria Rago, ${ }^{*}$ Ines Barone, ${ }^{*}$ Cinzia Giordano, ${ }^{\dagger}$ Francesca Giordano, ${ }^{*}$ Antonella Leggio, ${ }^{*}$ Alessandra Comandè, ${ }^{*}$ Angelo Liguori, ${ }^{*}$ Saveria Aquila, ${ }^{*}$ Daniela Bonofiglio, ${ }^{*}$ Sebastiano Andò, ${ }^{*}$ and Stefania Catalano*

From the Department of Pharmacy, Health and Nutritional Sciences, $*$ and the Centro Sanitario, ${ }^{\dagger}$ University of Calabria, Rende, Italy

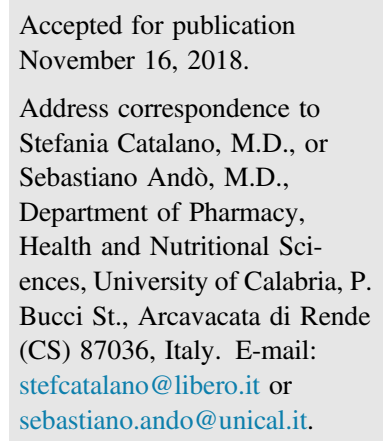

\begin{abstract}
Although in past decades the adipokine leptin and its own receptor have been considered as significant cancer biomarkers, their potential involvement in human testicular seminoma growth and progression remains unexplored. Here, we showed that the expression of leptin and its receptor was significantly higher in human testicular seminoma compared with normal adult testis. Human seminoma cell line TCam-2 also expressed leptin along with the long and short isoforms of leptin receptor, and in response to leptin treatment showed enhanced activation of its downstream effectors. In line with these results, leptin stimulation significantly increased the proliferation and migration of TCam-2 cells. Treatment of TCam-2 cells with the peptide Leu-Asp-Phe-Ile (LDFI), a full leptin-receptor antagonist, completely reversed the leptin-mediated effects on cell growth and motility as well as reduced the expression of several leptin-induced target genes. More importantly, the in vivo xenograft experiments showed that LDFI treatment markedly decreased seminoma tumor growth. Interestingly, LDFI-treated tumors showed reduced levels of the proliferation marker Ki-67 as well as decreased expression of leptin-regulated genes. Taken together, these data identify, for the first time, leptin as a key factor able to affect testicular seminoma behavior, highlighting leptin receptor as a potential target for novel potential treatments in this type of cancer. (Am J Pathol 2019, 189: 687-698; https://doi.org/10.1016/ j.ajpath.2018.11.012)
\end{abstract}

Testicular germ cell tumors (TGCTs) are the most commonly diagnosed solid malignancies in young men (aged 18 to 35 years), representing the leading cause of cancer-related morbidity and mortality in this age group. ${ }^{1,2}$ They are very heterogeneous cancers that are classified based on clinical and histologic features into seminomas and nonseminomas. ${ }^{3}$ Seminomas are the most frequent TGCTs, occurring either as pure form or as a component of a mixed germ cell tumor, and their incidence has been increasing over past decades worldwide. ${ }^{4,5}$ This type of cancer is successfully treated by orchiectomy followed by suitable radiotherapy at early stages, whereas cisplatinbased chemotherapy is curative for $70 \%$ to $80 \%$ of patients with advanced or metastatic disease. ${ }^{6}$ However, $20 \%$ to $30 \%$ of the patients show or develop a cisplatin resistance, which is associated with a poor prognosis. ${ }^{7,8}$ Moreover, several studies have reported long-term consequences of platinum-based therapies in survivors of testicular cancer such as cardiovascular disease, pulmonary dysfunction, neurotoxicity, kidney failure, hypogonadism, and secondary neoplasms. ${ }^{9-11}$ Importantly, long-term side effects of chemotherapy have a non-negligible impact on the quality of life of these young patients. Thus, there is a compelling need to identify novel therapeutic targets that may improve clinical outcomes.

Adipokines and their related signaling cascades recently were a subject of intensified research in the field of oncology and cancer therapeutics. Among adipokines, leptin, a pleiotropic molecule encoded by the Obese ( $O b$; official name $L E P$ ) gene, primarily known for its role in regulating food intake, body weight, and energy metabolism, has been well-

\footnotetext{
Supported by Italian Foundation for Cancer Research (FIRC) grant 16487 (L.G.), My First Italian Association for Cancer Research (AIRC) grant 16899 (I.B.), and AIRC Investigator grants 18602 (S.An.) and Projects of Relevant National Interest (PRIN2015) 2015B7M39T (S.An.).

S.An. and S.C. contributed equally to this work as senior authors.

Disclosures: None declared.
} 
Table 1 List of Antibodies Used for Immunofluorescence, Immunohistochemistry, and Immunoblot Analysis

\begin{tabular}{|c|c|c|c|}
\hline Antibodies & Company & $\begin{array}{l}\text { Catalog } \\
\text { number }\end{array}$ & Dilution \\
\hline Ki-67 & Santa Cruz Biotechnology & sc-7846 & $1: 100 \mathrm{IHC}$ \\
\hline $0 \mathrm{~b}$ & Santa Cruz Biotechnology & sc-842 & $\begin{array}{l}1: 500 \mathrm{IB} \\
1: 100 \mathrm{IHC} \\
1: 100 \mathrm{IF}\end{array}$ \\
\hline ObR & Santa Cruz Biotechnology & sc-8391 & $\begin{array}{l}1: 500 \text { IB } \\
1: 100 \text { IHC } \\
1: 100 \text { IF }\end{array}$ \\
\hline pAkt ${ }^{\operatorname{Ser} 473}$ & Santa Cruz Biotechnology & sc-7985 & $1: 500$ IB \\
\hline Akt & Santa Cruz Biotechnology & sc-81434 & $1: 500$ IB \\
\hline$\beta$-Actin & Santa Cruz Biotechnology & sc-69879 & $1: 5000$ IB \\
\hline pSTAT3 ${ }^{\text {Tyr705 }}$ & Cell Signaling Technology & $9138 \mathrm{~S}$ & 1:1000 IB \\
\hline STAT3 & Cell Signaling Technology & 9139S & $1: 1000$ IB \\
\hline pMAPK $^{\text {Thr202/Tyr204 }}$ & Cell Signaling Technology & $9101 \mathrm{~S}$ & 1:1000 IB \\
\hline MAPK & Cell Signaling Technology & $9102 S$ & 1:1000 IB \\
\hline
\end{tabular}

IB, immunoblot; IF, immunofluorescence; IHC, immunohistochemistry; MAPK, mitogen-activated protein kinase; 0b, leptin; 0bR, leptin receptor; PSTAT, phosphorylated signal transducer and activators of transcription.

recognized as a key player in the development and progression of a large variety of malignancies. ${ }^{12-14}$ The expression of leptin and its receptors (ObRs) have been reported in many cancer types in which this adipokine, through the activation of canonical [Janus kinase/signal transducer and activators of transcription; mitogen-activated protein kinase (MAPK)/ extracellular signal-regulated kinase 1/2, phosphoinositide-3- kinase/protein kinase B/Akt (PI3K-PKB/Akt) and noncanonical [protein kinase $\mathrm{C}$, c-Jun N-terminal kinase, p38 MAPK, nuclear factor- $\kappa \mathrm{B}$, and AMP-activated protein kinase (AMPK)] signaling pathways, increases cancer cell proliferation and transformation, exerts anti-apoptotic effects, induces the expression of cell-cycle modulators, and influences cancer migration and invasion. ${ }^{12-18}$ In addition, interaction of leptin with other important molecular effectors including estrogens, growth factors, and inflammatory cytokines further increases its impact on tumorogenesis. ${ }^{19-23}$ Recently, it also was reported that leptin signaling is able to induce cancer stem cells, which are involved in cancer recurrence and drug resistance. ${ }^{24-26}$ Thus, leptin/ObR signaling may be an attractive target for cancer prevention and therapy. Indeed, in the past few years several compounds have been described as potential tools to affect leptin-induced cancer growth and progression. ${ }^{14,27-29}$ Although leptin and its receptors have been detected in testicular cells, suggesting their direct involvement in testicular functions, ${ }^{30,31}$ their expression in human testicular seminoma as well as the role of this adipokine in the development and promotion of testicular seminoma remains largely unknown.

Therefore, our aim was to evaluate the expression of leptin and its receptors in human testicular seminoma and to explore the role of leptin on the growth and progression of TCam-2 cells, a well-documented experimental model for seminoma. The effects of inhibiting leptin signaling as a potential therapeutic target to reduce testicular cancer progression also was studied using both in vitro and in vivo models.

Table 2 Oligonucleotide Primers Used in This Study

\begin{tabular}{|c|c|c|}
\hline Gene name & Gene symbol & Primer sequences \\
\hline \multirow[t]{2}{*}{ Leptin } & $L E P$ & F: 5'-GTGCGGATTCTTGTGGCTTT-3' \\
\hline & & R: 5'-GGAATGAAGTCCAAACCGGTG-3' \\
\hline \multirow[t]{2}{*}{ Long-form leptin receptor } & $O B R L$ & F: 5'-TCACTCCGAAAGCAACAGTG-3' \\
\hline & & R: 5'-СTTTTGCCTGCTGGACTCTC-3' \\
\hline \multirow[t]{2}{*}{ Short-form leptin receptor } & OBRS & F: 5'-ATTGTGCCAGTAATTATTTCСTCTTCC-3' \\
\hline & & R: 5'-CCACCATATGTTAACTCTCAGAAGTTCAA-3' \\
\hline \multirow{2}{*}{ Matrix metalloproteinase- 9} & MMPg & F: 5'-AGTTCCCGGAGTGAGTTGAA-3' \\
\hline & & R: 5'-СТССАСТССТСССТТTССТС-3' \\
\hline \multirow[t]{2}{*}{ Aromatase } & CYP19A1 & F: 5'-ACCCTTCTGCGTCGTGTCA-3' \\
\hline & & R: 5'-TCTGTGGAAATCCTGCGTCTT-3' \\
\hline \multirow[t]{2}{*}{ Cyclin D1 } & CCND1 & F: 5'-GATGCCAACCTCCTCAACGAC-3' \\
\hline & & R: 5'-CTCCTCGCACTTCTGTTCCTC-3' \\
\hline & & R: 5'-CTCACCGCCTCGGCTTGTCAC-3' \\
\hline \multirow[t]{2}{*}{ Hypoxia-inducible factor $1-\alpha$} & HIF1A & F: 5'-TGCACAGGCCACATTCACGT-3' \\
\hline & & R: 5'-GTTCACAAATCAGCACCAAGC-3' \\
\hline \multirow[t]{2}{*}{ Survivin } & BIRC5 & F: 5'-GGACCACCGCATCTCTACAT-3' \\
\hline & & R: 5'-GTTGCGCTTTCCTTTCTGTC-3' \\
\hline \multirow[t]{2}{*}{ Glyceraldehyde 3-phosphate dehydrogenase } & GAPDH & F: 5'-CССАСТССТССАССТTTGAC-3' \\
\hline & & R: 5'-TGTTGCTAGCCAAATTCGTT-3' \\
\hline
\end{tabular}

$F$, forward; R, reverse. 

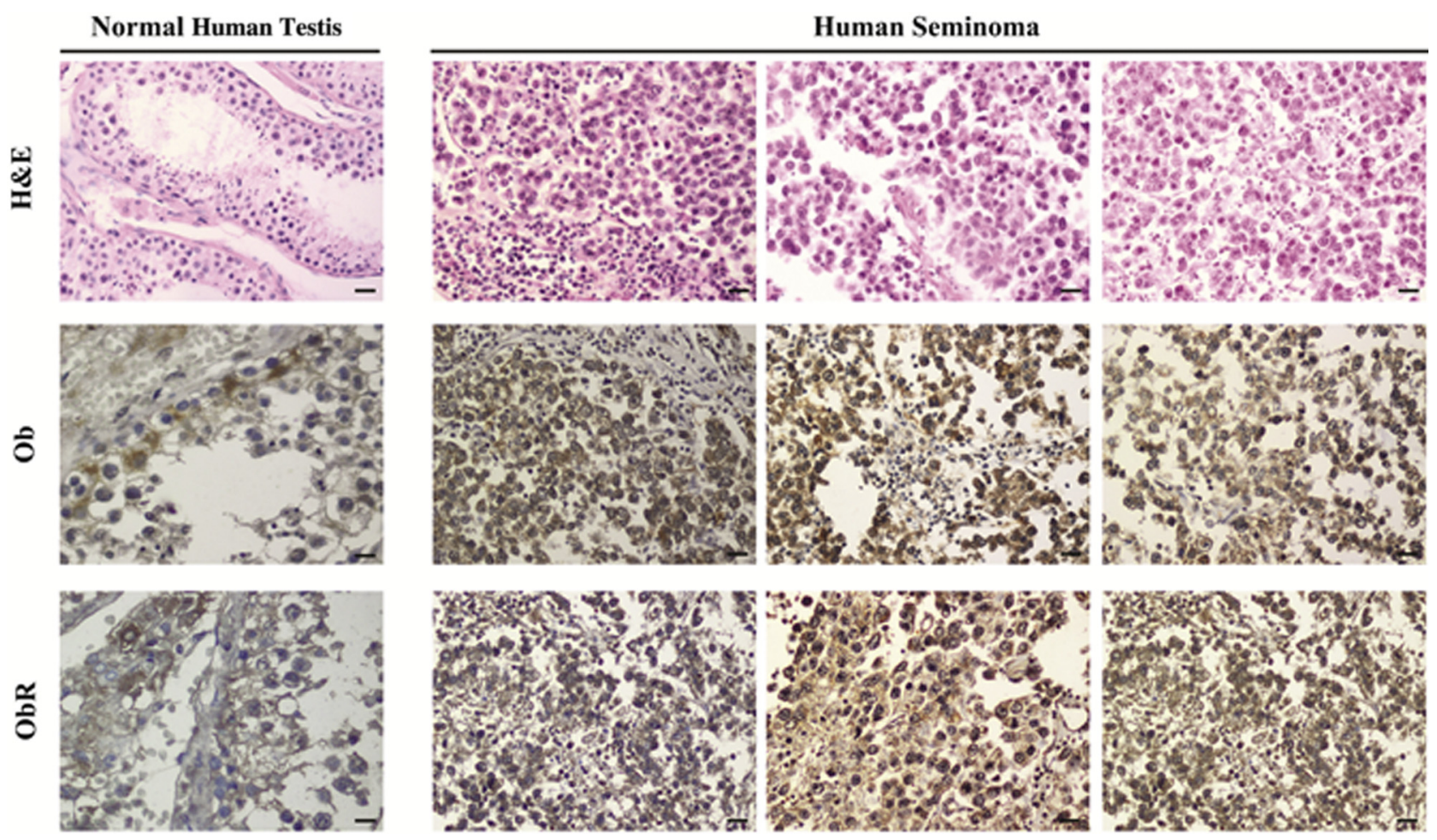

Figure 1 Protein expression of leptin (Ob) and its receptor (ObR) in normal human testis and seminoma tissues. Representative images of hematoxylin and eosin (H\&E) and immunohistochemistry analysis of $0 \mathrm{~b}$ and $\mathrm{ObR}$ in normal testis and in tumor tissues from seminoma patients. Scale bars: $12.5 \mu \mathrm{m}(0 \mathrm{~b}$ and $0 \mathrm{bR}$ in normal human testis); $25 \mu \mathrm{m}$ (H\&E in normal human testis, and $\mathrm{H} \& \mathrm{E}, \mathrm{Ob}$, and $\mathrm{ObR}$ in human seminoma).

\section{Materials and Methods}

\section{Reagents and Antibodies}

The following reagents and antibodies were used: leptin from Sigma (Milan, Italy). $\beta$-Actin/Ki-67 ObR/Ob/Akt/ pAkt ${ }^{\mathrm{Ser} 437}$ antibodies from Santa Cruz Biotechnology (Santa Cruz, CA), and MAPK/signal transducer and activators of transcription 3/pMAPK ${ }^{\text {Thr202/Tyr204/phosphory- }}$ lated signal transducer and activators of transcription $3^{\text {Tyr705 }}$ from Cell Signaling Technology (Beverly, MA). Antibodies used are listed in Table 1.

\section{Patients and Tissue Specimens}

A total of six testicular tumors and two non-neoplastic testicular tissues were analyzed in this study. Caucasian men have a greater risk of developing testicular cancer than black, AsianAmerican, or American-Indian men. Testicular tumors were obtained from Caucasian men with testicular germ cell tumors (seminoma) (age, 20 to 35 years) undergoing therapeutic orchidectomy at Annunziata Hospital (Cosenza, Italy). Nonneoplastic testicular tissues were obtained from two Caucasian men (aged 29 and 32 years) with testes with a granulomatous lesion collected from the same hospital. Tissue specimens were obtained from patients who signed informed consent at Annunziata Hospital. Fresh surgical tissues were formalin-fixed/ paraffin-embedded. Obtained sections were used for morphologic analyses by hematoxylin and eosin staining and immunohistochemical analyses. The clinical investigation was approved by the Ethics and Institutional Human Subject Committees at Annunziata Hospital.

Table 3 Immunohistochemistry Scores in Normal Human Testis and Human Seminoma

\begin{tabular}{lll}
\hline Samples & Ob & ObR \\
\hline $\begin{array}{l}\text { Normal human testis } \\
\text { Germ cells }\end{array}$ & \\
$\quad$ Control 1 & 0 & 1 \\
$\quad$ Control 2 & 0 & 2 \\
Sertoli cells & & \\
$\quad$ Control 1 & 3 & 2 \\
$\quad$ Control 2 & 2 & 2 \\
Leydig cells & & \\
Control 1 & 2 & 3 \\
$\quad$ Control 2 & 3 & 3 \\
Human seminoma & & \\
Patient 1 & $4^{*}$ & $3^{*}$ \\
Patient 2 & $3^{*}$ & $4^{*}$ \\
Patient 3 & $4^{*}$ & $4^{*}$ \\
Patient 4 & $3^{*}$ & $3^{*}$ \\
Patient 5 & $4^{*}$ & $4^{*}$ \\
Patient 6 & $4^{*}$ & $3^{*}$ \\
\hline
\end{tabular}

Staining intensity scores are as follows: $0=$ negative; $1=$ weak; $2=$ moderate; $3=$ strong; and $4=$ very strong.

${ }^{*} P<0.005$ versus germ cells of normal testis.

$0 b$, leptin; ObR leptin receptor. 
A

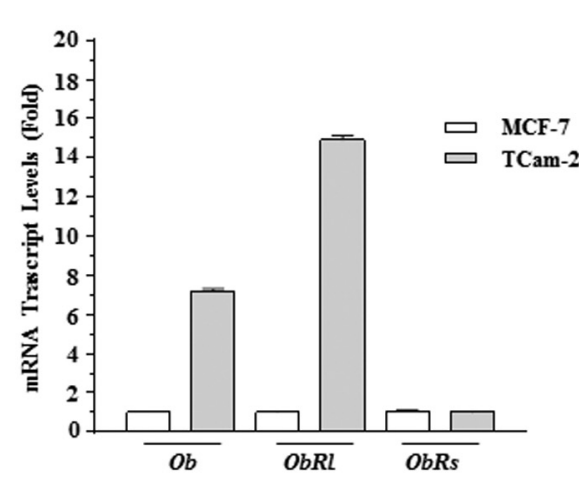

B

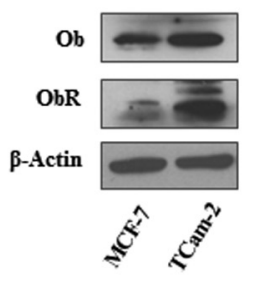

C

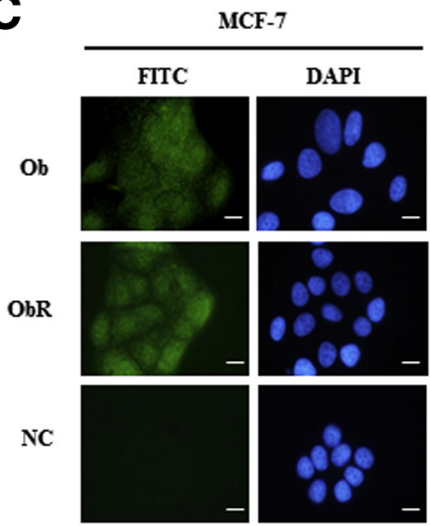

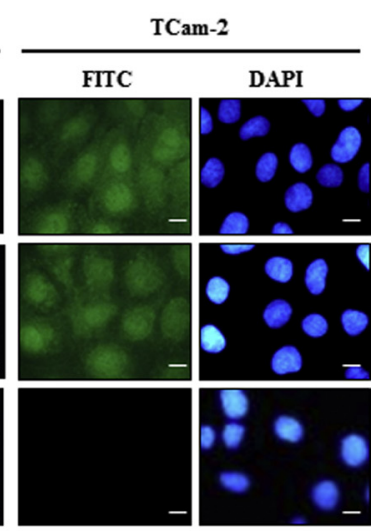

D
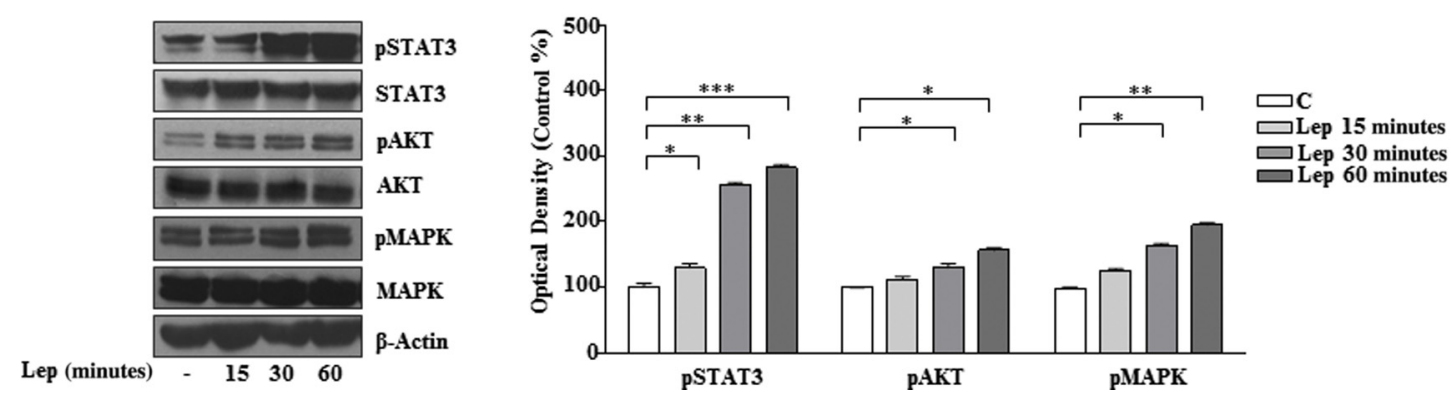

Figure 2 Leptin (Ob) and leptin-receptor expression (ObR) and signaling activation in TCam-2 cells. A: Real-time RT-PCR for Ob and ObR long and short isoforms (ObRL/ObRs). MCF-7 breast cancer cells were used as a positive control. B: Immunoblotting showing 0b and 0bR. MCF-7 breast cancer cells were used as a positive control. $\beta$-actin was used as loading control. C: Immunofluorescence of $0 \mathrm{~b}$ and $0 \mathrm{bR}$ and DAPI staining for nuclear detection. MCF-7 breast cancer cells were used as a positive control. D: Immunoblotting of phosphorylated signal transducer and activators of transcription (pSTAT)3/pAKT/phosphorylated mitogen-activated protein kinase (pMAPK) and total nonphosphorylated proteins from cells treated with vehicle (-) or $500 \mathrm{ng} / \mathrm{mL}$ leptin (Lep). $\beta$-Actin was used as loading control. The histograms represent the means \pm SD of three separate experiments in which band intensities were evaluated in terms of optical density arbitrary units and expressed as a percentage of vehicle-treated samples, which were assumed to be $100 \%$. ${ }^{*} P<0.05,{ }^{* *} P<0.01$, and ${ }^{* * *} P<0.001$. Scale bars $=5 \mu \mathrm{m}$. Original magnification, $\times 100$. FITC, fluorescein isothiocyanate; NC, negative control.

\section{Immunohistochemical Analysis}

Paraffin-embedded sections (5- $\mu \mathrm{m}$ thick) were mounted on polylysine-precoated slides, and then deparaffinized and dehydrated (seven to eight serial sections). Immunohistochemical experiments were performed after heat-mediated antigen retrieval. Hydrogen peroxide (3\% in distilled water) was used for 30 minutes to block endogenous peroxidase activity, and normal goat serum (10\%) was used for $30 \mathrm{mi}-$ nutes to prevent nonspecific binding. Immunodetection was performed using anti-Ob, anti-ObR, and anti-Ki-67 primary antibodies at $4{ }^{\circ} \mathrm{C}$ overnight, dilutions used are reported in Table 1 . Then, biotinylated goat-anti-rabbit and rabbit-antigoat IgG were applied for 1 hour at room temperature, followed by the avidin-biotin-horseradish peroxidase complex (Vector Laboratories, Burlingame, CA). Immunoreactivity was visualized using diaminobenzidine chromogen (Zymed Laboratories, South San Francisco, CA). In negative control sections normal serum was used instead of the primary antibody. The immunostained slides of tumor samples were visualized using an Olympus BX51 microscope (Olympus,
Tokyo, Japan) and the images were taken with CSV1.14 software (Olympus), using a CAM XC-30 (Olympus) for image acquisition. Immunoreactivity was evaluated by a pathologist in a blinded fashion (V.R.) and scored as: 0 , negative; 1 , weakly positive; 2 , moderately positive; 3 , strongly positive; and 4 , very strongly positive.

\section{Cell Culture}

The human TCam-2 seminoma cell line was a gift from Dr. Leendert H. J. Looijenga (Department of Pathology, Medical Center Rotterdam, Josephine Nefkens Institute, Rotterdam, the Netherlands), and was grown in RPMI-1640 plus $10 \%$ fetal bovine serum, $1 \%$ penicillin/streptomycin, and 200 $\mathrm{mmol} / \mathrm{L}$ glutamine, at $37^{\circ} \mathrm{C}$ in a humidified cell culture incubator with $5 \%$ carbon dioxide. Mizuno et $\mathrm{al}^{32}$ reported isolation and characterization of TCam-2 cells, which then were indicated, using a multidisciplinary approach as representative for human seminoma. ${ }^{33-35}$ MCF-7 breast cancer cells were cultured in Dulbecco's modified Eagle medium containing $10 \%$ fetal bovine serum, $1 \%$ L-glutamine, $1 \%$ 
A

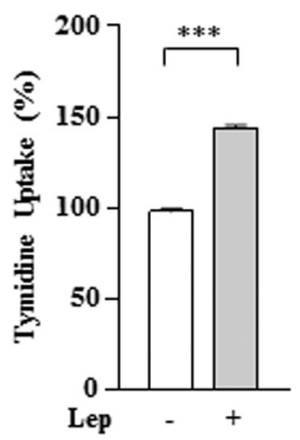

C

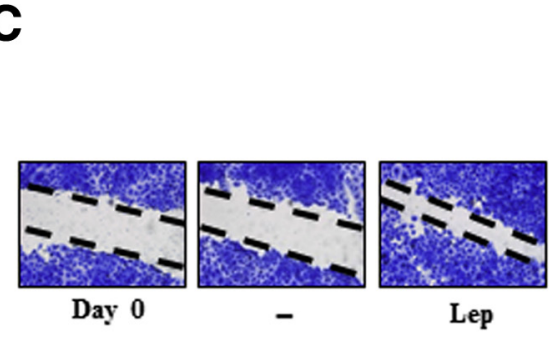

B

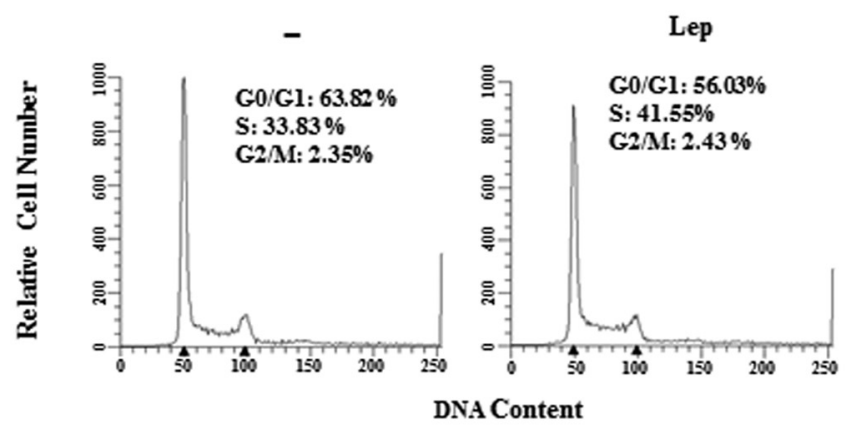

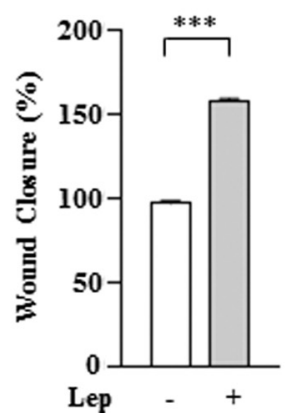

D
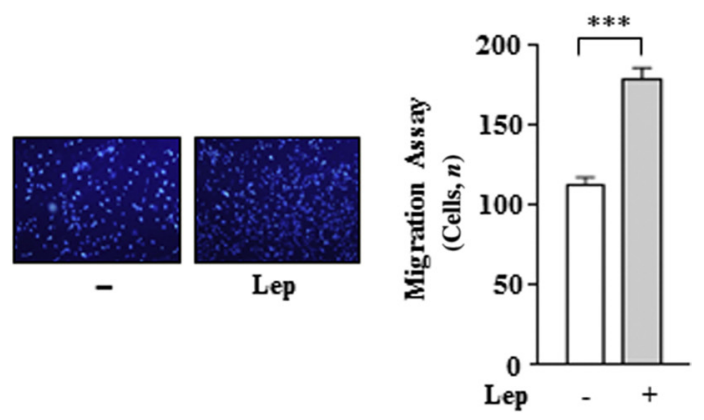

Figure 3 Impact of leptin on TCam-2 cell proliferation and motility. A: Cell proliferation was determined by $\left.{ }^{3} \mathrm{H}\right]$ thymidine incorporation assay after 24 hours of treatment with vehicle (-) or $500 \mathrm{ng} / \mathrm{mL}$ leptin (Lep). B: TCam-2 cells were treated with vehicle (-) or $500 \mathrm{ng} / \mathrm{mL}$ leptin (Lep) for 24 hours, stained with propidium iodide, and analyzed on a FACScan flow cytometer. Quantitative analysis of the percentage of gated cells at G0/G1, S, and G2/M phases is shown. Arrowheads indicate identified peaks. C: Wound healing assays in TCam-2 cells treated for 12 hours with vehicle (-) or $500 \mathrm{ng} / \mathrm{mL}$ leptin (Lep). Images are representative of three independent experiments. The histograms represent the relative percentage of wound closure calculated by ImageJ software version 1.51q. D: Boyden chamber transmigration assays in TCam-2 cells treated with vehicle (-) or $500 \mathrm{ng} / \mathrm{mL}$ leptin (Lep) for 12 hours. A representative image of transmigrated cells is shown. Data are expressed as means \pm SD of three different experiments, each performed in triplicate. Original magnification: $\times 10(\mathbf{C})$; $\times 20$ (D). ${ }^{* * *} P<0.001$.

Eagle's nonessential amino acids, and $1 \mathrm{mg} / \mathrm{mL}$ penicillinstreptomycin at $37^{\circ} \mathrm{C}$ with $5 \% \mathrm{CO}_{2}$ air. TCam-2 cells routinely were authenticated by evaluating the expression of the well-known specific biomarkers for seminoma cells as reported by Russel et al. ${ }^{33}$ The MCF-7 cell line was authenticated by short tandem repeats analysis at the Sequencing Core at University of Calabria (Rende, Italy).

\section{Quantitative Real-Time PCR Analysis}

Total RNA from TCam-2 cells was extracted using TRIzol reagent (Invitrogen, Carlsbad, CA) and gene expression was evaluated by real-time RT-PCR, using SYBR Green Universal PCR Master Mix (Bio-Rad, Segrate, Italy) as previously described. ${ }^{36}$ Each sample was normalized on GAPDH mRNA content. The relative gene expression levels were calculated as described. ${ }^{37}$ Primers are listed in Table 2.

\section{Immunoblot Analysis}

Cell extracts were resolved by SDS-PAGE as described. ${ }^{38}$ Blots are representative of three separate experiments. The bands of interest were quantified by the Scion Image laser densitometry scanning program (ImageJ version 1.51q; NIH,
Bethesda, MD) and SDs along with associated $P$ values for the replicates were calculated by GraphPad Prism 4 software (GraphPad, Inc., San Diego, CA).

\section{Immunofluorescence}

Immunofluorescence microscopy analysis was conducted as described. ${ }^{39}$ Briefly, cells were fixed with $4 \%$ paraformaldehyde, permeabilized with phosphate-buffered saline $0.2 \%$ Triton X-100 (Sigma), blocked with $5 \%$ bovine serum albumin (1 hour at room temperature), and incubated with anti-Ob and anti-ObR primary antibody $\left(4^{\circ} \mathrm{C}\right.$, overnight; dilutions used are listed in Table 1), followed by fluorescein isothiocyanate-conjugated secondary antibody (30 minutes at room temperature). IgG primary antibody was used as negative control. DAPI (Sigma) staining was used for nuclei detection. Fluorescence was captured with an Olympus BX51 microscope (100× objective).

\section{Enzyme-Linked Immunosorbent Assay}

Leptin levels were detected using the Enzyme-Linked Immunosorbent Assay kit (Labor Diagnostika Nord, Nordhorn, 


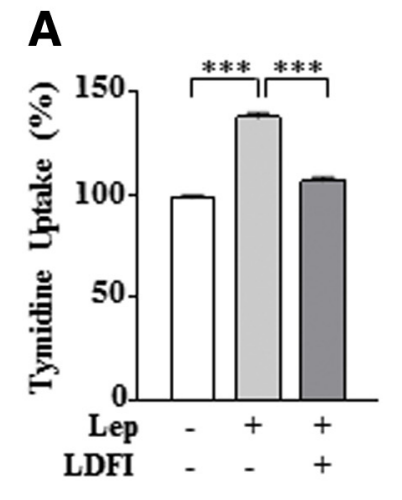

B

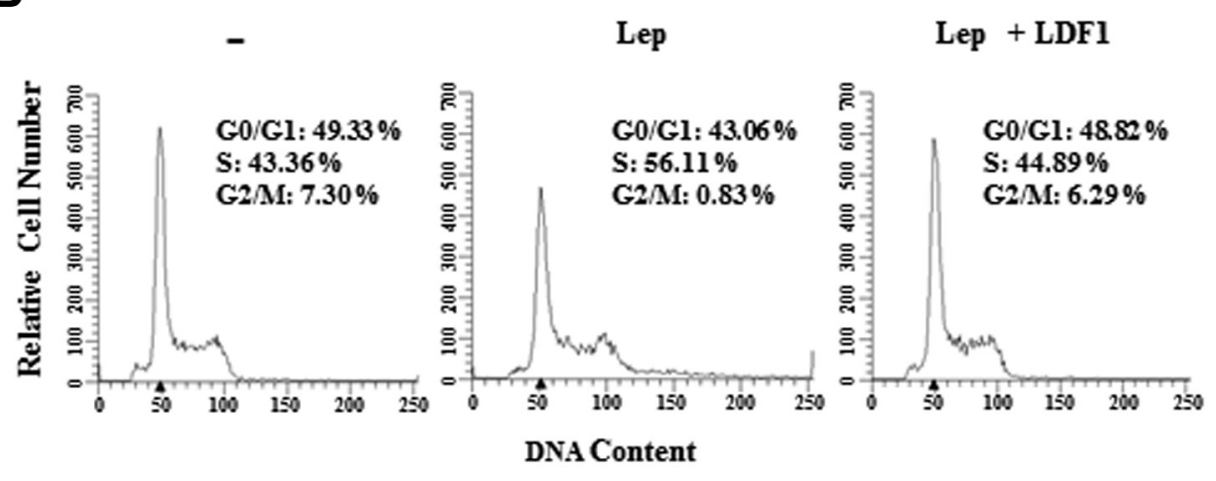

C

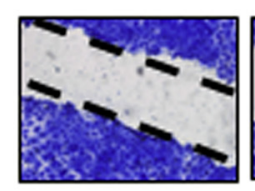

Day 0

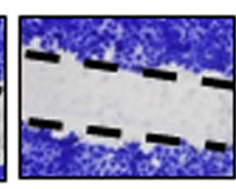

-

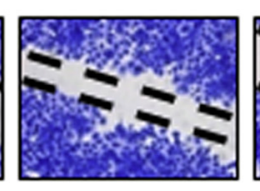

Lep

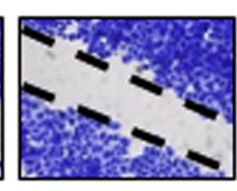

Lep+LDFI

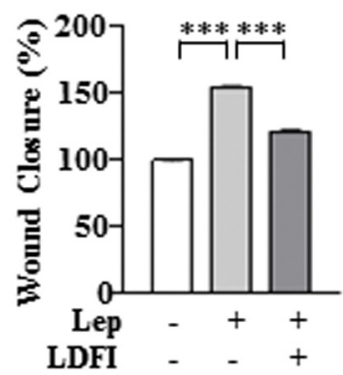

D

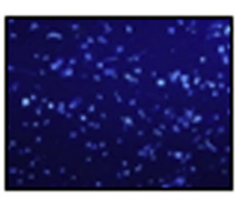

$-$

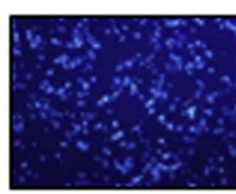

Lep

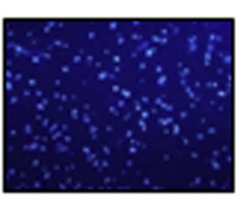

Lep+LDFI

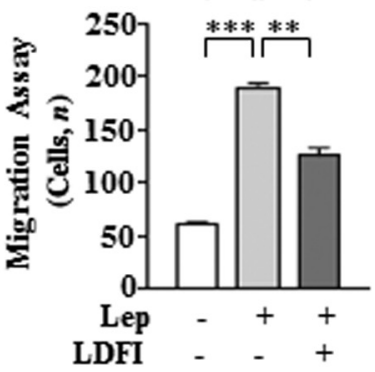

E
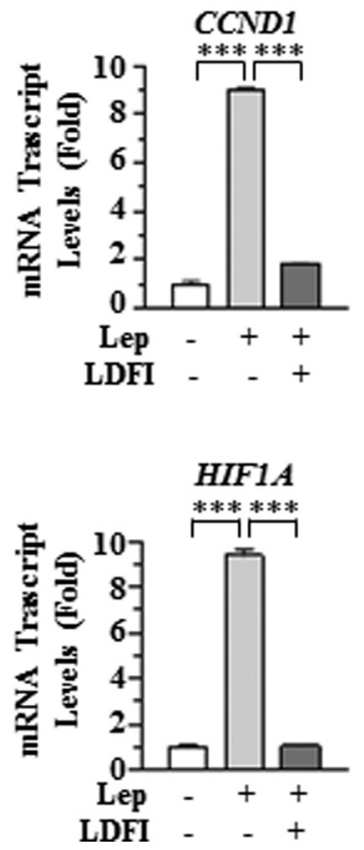

BIRC5
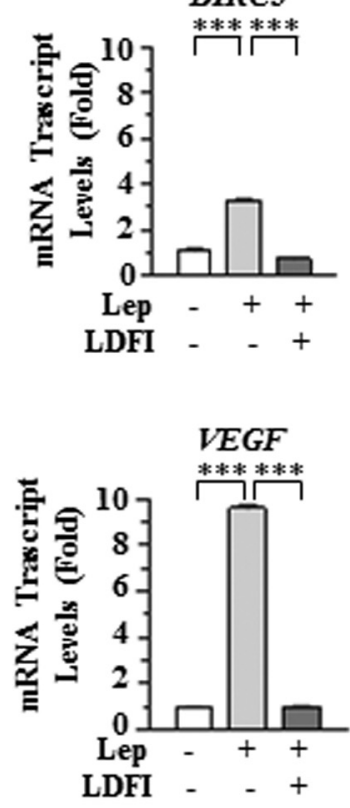

HSP9OA

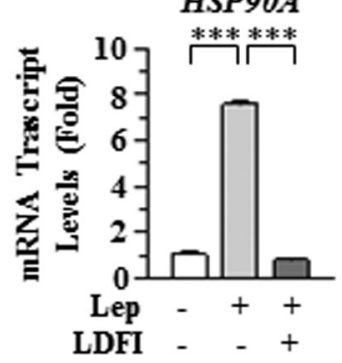

MMP2

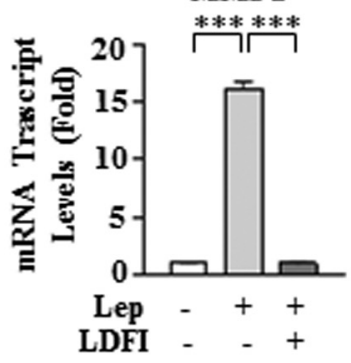

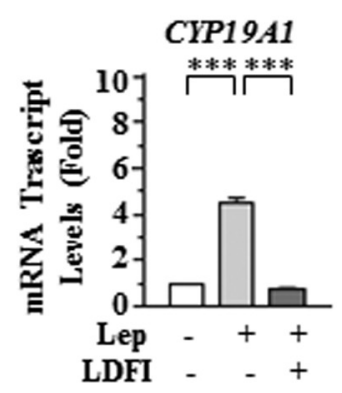

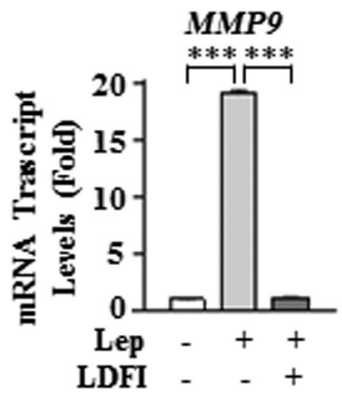


Germany) according to the manufacturer's instructions. Results are presented as picograms per milligram of protein.

\section{$\left[{ }^{3} \mathrm{H}\right]$ Thymidine Incorporation}

TCam-2 cells were treated with leptin with/without peptide Leu-Asp-Phe-Ile (LDFI) synthesized by solid-phase methodologies ${ }^{40}$ for 24 hours. For the last 6 hours, $\left[{ }^{3} \mathrm{H}\right]$ thymidine $(1 \mu \mathrm{Ci} / \mathrm{mL})$ was added to the culture medium. At the end of incubation, cells were washed once with $10 \%$ and three times with $5 \%$ trichloroacetic acid, lyzed in $0.1 \mathrm{~N}$ $\mathrm{NaOH}$ for 30 minutes at $37^{\circ} \mathrm{C}$. $\left[{ }^{3} \mathrm{H}\right]$ thymidine incorporation was determined by scintillation counting.

\section{DNA Flow Cytometry}

To perform cell-cycle analysis, cells were collected by trypsinization, fixed, and stained with $100 \mu \mathrm{g} / \mathrm{mL}$ propidium iodide after treatment with $20 \mu \mathrm{g} / \mathrm{mL}$ RNase A. The DNA content was determined with a FACScan flow cytometer (Becton Dickinson, Mountain View, CA) and the data were acquired with CellQuest software version 3.3 (BD Biosciences, San Jose, CA). Cell-cycle profiles were analyzed with ModFit LT version version 3.3 (BD Biosciences).

\section{Wound-Healing Assays}

Cell migration was monitored and the rate of wound healing was quantified as reported. ${ }^{41}$ Briefly, cell monolayers were scraped and subjected to the different experimental conditions as indicated. Images are representative of three independent experiments $(10 \times$ magnification). The rate of wound healing was quantified from the images using Scion Image and Adobe Photoshop software CC 2015 (Adobe Systems Incorporated, San Jose, CA), and SDs along with associated $P$ values for the replicates were calculated by GraphPad Prism 4 software (GraphPad, Inc.).

\section{Transmigration Assays}

Cells treated with leptin with/without peptide LDFI were placed in the upper compartments of a Boyden chamber $(8-\mu \mathrm{m}$ membranes; Corning Costar, Bedford, MA). The bottom well contained regular full media. After 6 hours, migrated cells were fixed and stained with Coomassie brilliant blue (Sigma). Migration was quantified by viewing five separate fields per membrane at $20 \times$ magnification and expressed as the mean number of migrated cells. Data represent three independent experiments, performed in triplicate.

\section{In Vivo Experiments}

The in vivo experiments were performed in 30-day-old male nude mice (nu/nu Swiss; Charles River, Milan, Italy) maintained in a sterile environment. At day 0 , TCam- 2 cells $\left(1.0 \times 10^{6}\right.$ cells per mouse) were inoculated into the intrascapular region, in $0.1 \mathrm{~mL}$ of Matrigel (Corning Costar). When the mean tumor size reached approximatively $100 \mathrm{~mm}^{3}$ of volume the mice were randomized into two groups $(5 \mathrm{mice} /$ group). The mice then were treated with LDFI-polyethylene glycol (PEG) $(10 \mathrm{mg} / \mathrm{kg} /$ day $)$ diluted in saline $0.3 \%$ bovine serum albumin or saline $0.3 \%$ bovine serum albumin only (vehicle) by i.p. injection. The treatment was delivered 5 days a week. Tumor development was followed twice a week by caliper measurements along two orthogonal axes: length (L) and width (W). The volume (V) of tumors was estimated by the following formula: $\mathrm{V}=\mathrm{L}\left(\mathrm{W}^{2}\right) / 2$.

Relative tumor volume (RTV) was calculated from the following formula: $\mathrm{RTV}=(\mathrm{Vx} / \mathrm{V} 1)$, where $\mathrm{Vx}$ is the tumor volume on day $\mathrm{X}$ and $\mathrm{V} 1$ is the tumor volume at initiation of the treatment. The growth curve was obtained by plotting the mean volume of RTV on $y$ axis against time ( $x$ axis expressed as days after starting treatment). Antitumor activity was evaluated according to tumor growth inhibition, calculated from the following formula: percentage growth inhibition $=100-$ $(\mathrm{RTVt} / \mathrm{RTVc}) \times 100$, where RTVt is the medium RTV of treated mice and RTVc is the median RTV of controls, both at a given time point when the antitumor effect was optimal. At the time of sacrifice, tumors were dissected out from the neighboring connective tissue, frozen, and stored in nitrogen for further analysis. The remaining tumor tissues from each sample were fixed in $4 \%$ paraformaldehyde and embedded in paraffin for histologic analyses. All animals were maintained and handled in accordance with the recommendation of the Guidelines for the Care and Use of Laboratory Animals and were approved by the Animal Care Committee of University of Calabria, Rende, Italy.

\section{Histopathologic Analysis}

Tumors, liver, lungs, spleens, kidneys, and testis were fixed in $4 \%$ formalin, sectioned at $5 \mu \mathrm{m}$, and stained with hematoxylin and eosin yellowish, as suggested by the manufacturer (Bio-Optica, Milan, Italy).

Figure 4 Effects of peptide Leu-Asp-Phe-Ile (LDFI) on leptin-induced TCam-2 cell proliferation and migration. A: $\left[{ }^{3} \mathrm{H}\right]$ thymidine incorporation in TCam-2 cells treated with vehicle (-), $500 \mathrm{ng} / \mathrm{mL}$ leptin (Lep), or leptin $+1 \mu \mathrm{mol} / \mathrm{L}$ LDFI for 24 hours. B: TCam-2 cells were treated with vehicle (-), $500 \mathrm{ng} / \mathrm{mL}$ leptin (Lep), or leptin $+1 \mu \mathrm{mol} / \mathrm{L}$ LDFI for 24 hours, stained with propidium iodide, and analyzed on a FACScan flow cytometer. Quantitative analysis of the percentage of gated cells at G0/G1, S, and G2/M phases are shown. Arrowheads indicate identified peaks. C: Wound healing assays in TCam-2 cells treated for 12 hours with vehicle $(-), 500 \mathrm{ng} / \mathrm{mL}$ leptin (Lep), or leptin $+1 \mu \mathrm{mol} / \mathrm{L}$ LDFI. Images are representative of three independent experiments. The histograms represent the relative percentage of wound closure calculated by ImageJ software version 1.51q. D: Boyden chamber transmigration assays in TCam-2 cells treated with vehicle $(-), 500 \mathrm{ng} / \mathrm{mL}$ leptin (Lep), or leptin $+1 \mu \mathrm{mol} / \mathrm{L}$ LDFI for 12 hours. E: Real-time RT-PCR for mRNA of a subset of genes in TCam-2 cells treated for 24 hours with vehicle $(-), 500 \mathrm{ng} / \mathrm{mL}$ leptin (Lep), or leptin $+1 \mu \mathrm{mol} / \mathrm{L}$ LDFI. Data are expressed as means \pm SD of three different experiments, each performed in triplicate. Original magnification: $\times 10$ (C); $\times 20$ (D). ${ }^{* *} P<0.01,{ }^{* * *} P<0.001$. 
A

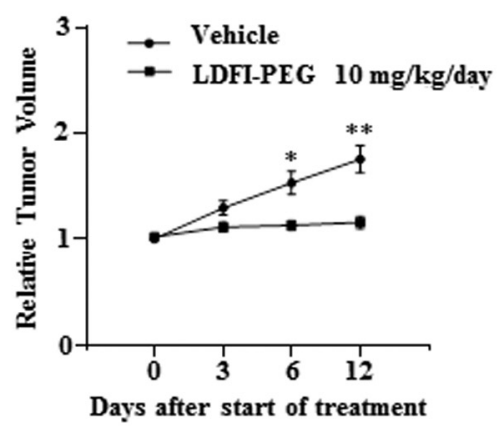

B

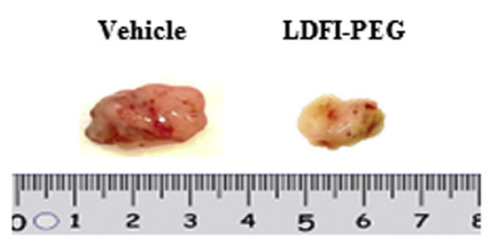

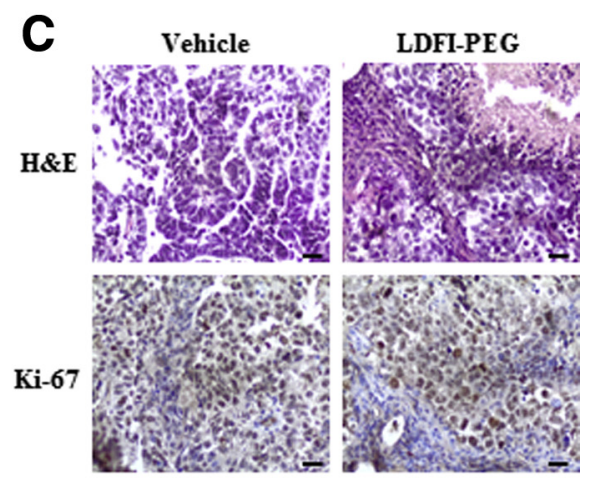

HSP9OA
D
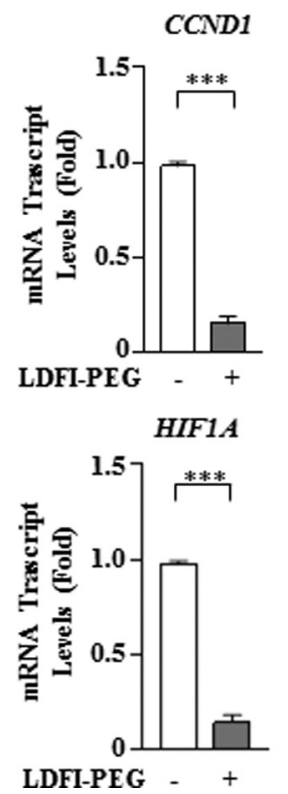
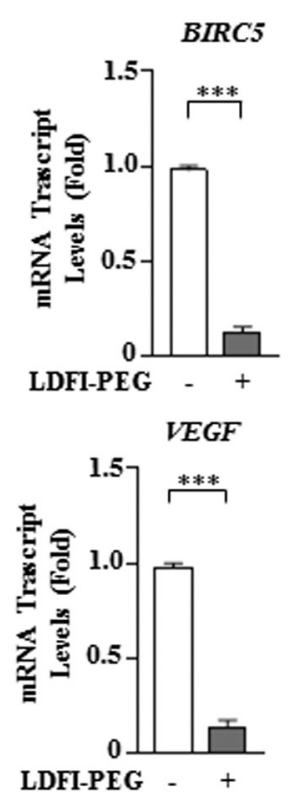
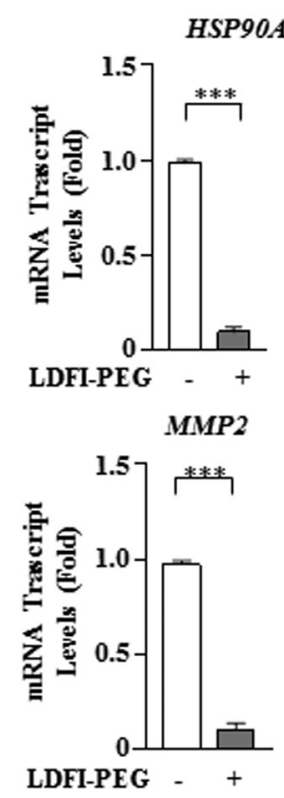
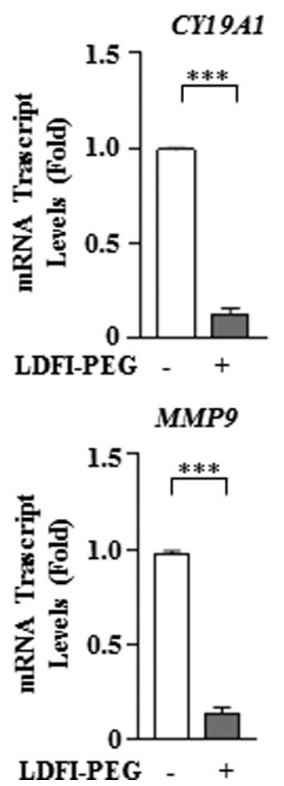

Figure 5 Impact of Leu-Asp-Phe-Ile (LDFI)-polyethylene glycol (PEG) treatment on tumor growth of TCam-2 xenografts. A: TCam-2 cells were injected subcutaneously in male nude mice and then treated 5 days a week with vehicle (-) or $10 \mathrm{mg} / \mathrm{kg} /$ day peptide LDFI-PEG by i.p. injection (five mice per group). Relative tumor volume (RTV) was calculated by the following formula: RTV $=(V \times / V 1)$, where Vx is the tumor volume on day $x$ and V1 is the tumor volume at initiation of treatment (day 0). $y$ axis: means \pm SD of the RTV. B: Images of a representative individual tumor from each treatment group. C: Hematoxylin and eosin (H\&E) and Ki-67 staining of tumor sections from vehicle- (-) and LDFI-PEG -treated mice. D: Real-time RT-PCR for mRNA of a subset of genes from tumors excised from vehicle- $(-)$ and $10 \mathrm{mg} / \mathrm{kg} /$ day LDFI-PEG - treated mice. Data are expressed as means \pm SD of three different experiments, each performed in triplicate. ${ }^{*} P<0.05,{ }^{*} P<<0.01$, and ${ }^{* * *} P<0.001$ versus LDFI-PEG treatment. Scale bars $=25 \mu \mathrm{m}$ (C).

\section{Statistical Analysis}

Each datum point represents the means $\pm \mathrm{SD}$ of three different experiments. Data were analyzed for statistical significance $(P<0.05)$ using a two-tailed $t$-test, performed by GraphPad Prism 4.

For immunohistochemistry, one-way analysis of variance was used to evaluate the differences in the scores between tumor and control samples.

\section{Results}

Leptin and Leptin-Receptor Expression in Human Seminoma Tissues

The expression levels of leptin $(\mathrm{Ob})$ and leptin receptor $(\mathrm{ObR})$ were evaluated in six testicular seminoma sections and two normal testis samples by immunohistochemistry analysis. In the normal testis, a strong immunoreactivity for $\mathrm{Ob}$ was detected predominantly in the cytoplasm of Sertoli cells (Figure 1 and Table 3). Leydig cells showed weak $\mathrm{Ob}$ expression, whereas in germ cells this protein was undetectable (Figure 1 and Table 3). A positive ObR immunostaining was shown within the cytoplasm and at the membrane of Leydig cells whereas a very faint immunoreactivity was present in the tubular compartment (Figure 1 and Table 3). Testicular seminoma samples showed a uniform population of round/polygonal big neoplastic cells with well-defined borders. Extensive leukocyte infiltration was observed in all samples (Figure 1). Immunostaining of all testicular seminoma specimens showed intense $\mathrm{Ob}$ and ObR protein immunoreactivity in the cytoplasm of neoplastic cells, whereas the leukocytes were immunonegative (Figure 1). Compared with germ cells of normal 
testis tissues, expression levels of $\mathrm{Ob}$ and $\mathrm{ObR}$ were upregulated significantly in tumor tissues $(P<0.01)$ (Table 3$)$.

\section{Human Seminoma Cell Line TCam-2 Expresses a Functional Leptin Receptor}

The expression of leptin and its receptors was evaluated in the TCam-2 cell line, a well-documented experimental model that very closely resembles a seminoma in cell culture. ${ }^{33-35}$ Quantitative RT-PCR analysis showed the presence of $O b$ mRNA transcript as well as the long $(O b R l)$ and the short (ObRs) isoform of leptin receptor in TCam-2 cells (Figure 2A). The expression of both $\mathrm{Ob}$ and $\mathrm{ObR}$ then were confirmed at the protein level by using immunoblotting (Figure 2B) and immunofluorescent staining (Figure 2C). Moreover, enzyme-linked immunosorbent assay measurement in conditioned media from TCam-2 cells showed that leptin levels were $193 \pm 0.12 \mathrm{pg} / \mathrm{mg}$ protein.

The binding of leptin to its specific receptor leads to the activation of several intracellular signaling pathways. Thus, time course-response studies were performed to analyze phosphorylation levels of leptin downstream effectors using immunoblot analysis. Leptin treatment $(500 \mathrm{ng} / \mathrm{mL})$ induced a significant increase in the phosphorylation status of signal transducer and activators of transcription 3, Akt, and MAPK in the TCam-2 cell line (Figure 2D).

These results provide evidence for the first time that $\mathrm{Ob}$ and a functional ObR are present in human seminoma cells.

\section{Leptin Receptor Is Involved in Leptin-Mediated Growth and Migration of TCam-2 Cells}

Because ObR expression was increased in seminoma samples and leptin has been shown to promote growth and migration of various cancer cells, the effects of leptin were tested on the proliferation and motility of TCam-2 cells. By using a thymidine incorporation assay, leptin treatment (500 $\mathrm{ng} / \mathrm{mL}$ ) was found to enhance TCam-2 cell growth significantly compared with the vehicle-treated cells (Figure 3A).

These data correlated well with data obtained from flow cytometric analysis. TCam- 2 cells were synchronized by 48 hours of serum starvation and then induced to re-enter the cell cycle after 24 hours of leptin treatment. Exposure to leptin reduced the percentage of cells in the G0-/G1-phase of the cell cycle and increased the fraction of the cells in S-phase, compared with the control group (Figure 3B). Moreover, the data clearly showed that leptin significantly increased cell migration in both wound-healing scratch (Figure 3C) and transmigration (Figure 3D) assays.

Pretreatment of TCam- 2 cells with the peptide LDFI, a full leptin receptor antagonist, ${ }^{24,42}$ completely reversed the leptinmediated effects on cell growth and motility (Figure 4, A-D).

To extend the results obtained, the impact of LDFI on the expression of well-known leptin target genes involved in cell proliferation and progression also was evaluated. $^{19,43-48}$ Interestingly, the addition of the ObR antagonist LDFI strongly reduced leptin induction on cyclin D1 (CCDN1), survivin (BIRC5), HSP90A, aromatase (CYP19A1), hypoxia-inducible factor 1- $\alpha$ (HYF1A), vascular endothelial growth factor $(V E G F)$, and matrix metalloproteinase-2 (MMP2) and -9 (MMP9) mRNA levels (Figure 4E).

Collectively, these findings indicate a role for an activated leptin/leptin-receptor axis in promoting the growth and migration of human seminoma cells.

\section{LDFI Treatment Inhibits Tumor Growth in TCam-2 Xenografts}

Finally, to assess the therapeutic potential of the ObR antagonist LDFI on seminoma cells in vivo, xenograft tumors were established by subcutaneous inoculation of TCam- 2 cells in male nude mice. To increase the peptide bioavailability, a pegylated leptin-receptor antagonist $(\text { LDFI-PEG })^{42}$ we used and tumor growth was followed up after administration of LDFI-PEG at $10 \mathrm{mg} / \mathrm{kg} /$ day. Because TCam-2 express both leptin and ObR, exogenous leptin was not inoculated into the mice as previously reported in other cancer xenograft studies. ${ }^{42,49,50}$ The safety and tolerability of the peptide LDFI-PEG was proven by the evidence that no changes in body weight or in food and water consumption were observed, as well as no significant differences in the mean weights or histologic features of the major organs (liver, lung, spleen, and kidney) after sacrifice between vehicle- and LDFI-PEG-treated mice.

Tumor volume was measured from the first day of treatment and the RTV was calculated as described in detail in Materials and Methods. After LDFI-PEG treatment, tumor volumes continued to reduce compared with controls for the duration of the experiment (Figure 5A). Specifically, at the end of treatment, PEG-LDFI induced a significant tumor growth inhibition (44\%) compared with vehicletreated mice and tumor size was reduced markedly in LDFI-PEG-treated animals (Figure 5B). In parallel with the decrease in tumor size, a decrease of Ki-67 expression, a well-known cell proliferation marker, was observed (Figure 5C). In addition, accordingly with the in vitro data, real-time RT-PCR analysis showed that the expression of leptin-regulated genes was significantly lower in TCam-2 xenograft tumors from mice treated with LDFI-PEG than in tumors from vehicle-treated controls (Figure 5D).

\section{Discussion}

Despite an excellent survival rate, TGCTs still remain a significant cause of death in adult young men and the clinical management of TGCT patients is unchanged since the introduction of cisplatin-based chemotherapy into clinical practice in the late 1970s. The success of this therapy is limited by high toxicity, long-term side effects, and the problem of resistance rendering it necessary to individuate 
new therapeutic targets in the perspective of a multifaceted treatment to improve clinical outcomes.

Here, ObR was identified as a potential therapeutic target in testicular seminoma, the most common TGCT during reproductive age. Indeed, the adipocyte-derived cytokine leptin and its receptor are expressed at a high level in human seminoma tissues and inhibition of leptin signaling is able to reduce testicular cancer progression both in vitro and in vivo.

Increasing evidence has recognized the crucial role of leptin in cancer development.

Indeed, the expression of leptin and its receptor are found in a wide range of tumors including breast, colorectal, ovarian, endometrial, and genitourinary, wherein it has been shown that leptin-dependent signaling regulates several key processes of cancer progression including cell proliferation, inflammation, angiogenesis, metastasis, and drug resistance. In addition, increased expression of leptin and its receptor were found to be associated with a higher incidence, increased progression, and poor prognosis of several human cancers. ${ }^{12-18}$ To date, however, the potential role of leptin in human seminoma has never been explored.

To date, we know that leptin plays a crucial role in controlling reproductive function, acting on all levels of the hypothalamus-pituitary-gonadal axis, and also may have local effects on the function of testis. ${ }^{30,31}$ Leptin and its functional receptor have been detected in prepubertal and adult testes, even though with several differences in cellular localization among species, suggesting the potential for leptin to directly modulate testicular functions. In particular, it has been reported that testicular steroidogenesis as well as germ and Sertoli cell function may be modulated by leptin, either as autocrine/paracrine or endocrine signals. ${ }^{51-55}$

Here, for the first time, leptin $(\mathrm{Ob})$ and $\mathrm{ObR}$ expression was shown in human testicular seminoma and a significant increase was found in their expression in testicular tumors when compared with non-neoplastic testicular tissues. The in vitro results showed $\mathrm{Ob}$ expression and leptin secretion in TCam-2 cells, a cell line that very closely resembles a seminoma in cell culture. TCam-2 cells also expressed the long and short isoforms of ObR, implying that an autocrine feedback loop may exist. Moreover, leptin treatment induced an activation of its intracellular signaling, highlighting the presence of a functional ObR, and significantly promotes the proliferation and migration of TCam-2 cells.

The multifaceted oncogenic role of leptin has generated a growing interest in the design and development of several therapeutic strategies that could interfere with its action and thereby prevent or delay cancer initiation and progression. A number of leptin-receptor antagonists have been developed as mutants of the full protein, peptide fragments representing a single-receptor binding site, leptin-receptor monoclonal antibodies or nanobodies, and soluble leptin-receptor variants with several completing preclinical testing, indicating their possible use in anticancer therapies. ${ }^{14,27-29,56}$ We previously designed and tested a small peptide based on the wild-type sequence of leptin binding site I, named LDFI, that acts as a full leptin-receptor antagonist. $^{24,42}$ In particular, this peptide inhibits leptininduced breast cancer growth in vitro and shows antineoplastic activities in vivo. ${ }^{24,42}$

In the current study, it was shown that treatment with peptide LDFI significantly reduced the leptin-induced growth and motility in TCam- 2 cells. The antitumor action of this peptide was associated with the inhibition of several leptin-induced target genes including CCND1, BIRC5, HSP90A, CYP19A1, HIF1A, VEGF, MMP2, and $M M P 9$, all key players for cell growth and migration in other cancer cell types.

The physiological relevance of the inhibitory effects exerted by the ObR antagonist LDFI on seminoma tumor cell growth is pointed out by the in vivo studies showing that treatment with LDFI-PEG significantly decreases the growth of TCam-2 xenografts. Moreover, in tumor sections from LDFI-treated mice a marked decrease in the expression of the nuclear proliferation antigen Ki-67 as well as in the expression of leptin-regulated genes was observed.

In conclusion, results from the present investigation strongly support the hypothesis that leptin signaling plays an important role in the growth and progression of human testicular seminoma, highlighting the possibility that targeting the leptin receptor may be helpful in improving new molecular and pharmacologic approaches for the treatment of testicular seminoma patients.

\section{Acknowledgment}

The human TCam-2 seminoma cell line was a gift from by Dr. Leendert H.J. Looijenga (Josephine Nefkens Institute, Rotterdam, the Netherlands).

\section{References}

1. Ye H, Ulbright TM: Difficult differential diagnoses in testicular pathology. Arch Pathol Lab Med 2012, 136:435-446

2. Znaor A, Lortet-Tieulent J, Jemal A, Bray F: International variations and trends in testicular cancer incidence and mortality. Eur Urol 2014, 65:1095-1106

3. Chieffi P: Recent advances in molecular and cell biology of testicular germ-cell tumors. Int Rev Cell Mol Biol 2014, 312:79-100

4. Dieckmann KP, Richter-Simonsen H, Kulejewski M, Ikogho R, Zecha H, Anheuser P, Pichlmeier U, Isbarn H: Testicular germ-cell tumours: a descriptive analysis of clinical characteristics at first presentation. Urol Int 2018, 100:409-419

5. Ghazarian AA, Kelly SP, Altekruse SF, Rosenberg PS, McGlynn KA: Future of testicular germ cell tumor incidence in the United States: forecast through 2026. Cancer 2017, 123:2320-2328

6. Domont J, Massard C, Patrikidou A, Bossi A, de Crevoisier R Rose M, Wibault P, Fizazi K: A risk-adapted strategy of radiotherapy or cisplatin-based chemotherapy in stage II seminoma. Urol Oncol 2013, 31:697-705 
7. Kalavska K, Conteduca V, De Giorgi U, Mego M: Molecular mechanisms of resistance in testicular germ cell tumors - clinical implications. Curr Cancer Drug Targets 2018, 18:967-978

8. Jacobsen C, Honecker F: Cisplatin resistance in germ cell tumours: models and mechanisms. Andrology 2015, 3:111-121

9. Maroto P, Anguera G, Martin C: Long-term toxicity of the treatment for germ cell-cancer. Crit Rev Oncol Hematol 2018, 121:62-67

10. Chovanec M, Abu Zaid M, Hanna N, El-Kouri N, Einhorn LH, Albany C: Long-term toxicity of cisplatin in germ-cell tumor survivors. Ann Oncol 2017, 28:2670-2679

11. Sprauten M, Darrah TH, Peterson DR, Campbell ME, Hannigan RE, Cvancarova M, Beard C, Haugnes HS, Fosså SD, Oldenburg J, Travis LB: Impact of long-term serum platinum concentrations on neuro- and ototoxicity in cisplatin-treated survivors of testicular cancer. J Clin Oncol 2012, 30:300-307

12. Lin TC, Huang KW, Liu CW, Chang YC, Lin WM, Yang TY, Hsiao M: Leptin signaling axis specifically associates with clinical prognosis and is multifunctional in regulating cancer progression. Oncotarget 2018, 9:17210-17219

13. Ray A, Cleary MP: The potential role of leptin in tumor invasion and metastasis. Cytokine Growth Factor Rev 2017, 38:80-97

14. Candelaria PV, Rampoldi A, Harbuzariu A, Gonzalez-Perez RR: Leptin signaling and cancer chemoresistance: perspectives. World J Clin Oncol 2017, 10:106-119

15. Lipsey CC, Harbuzariu A, Daley-Brown D, Gonzalez-Perez RR: Oncogenic role of leptin and Notch interleukin-1 leptin crosstalk outcome in cancer. World J Methodol 2016, 6:43-55

16. Ahima RS, Osei SY: Leptin signaling. Physiol Behav 2004, 81: 223-241

17. Andò $S$, Catalano $S$ : The multifactorial role of leptin in driving the breast cancer microenvironment. Nat Rev Endocrinol 2011, 8:263-275

18. Andò S, Barone I, Giordano C, Bonofiglio D, Catalano S: The multifaceted mechanism of leptin signaling within tumor microenvironment in driving breast cancer growth and progression. Front Oncol $2014,4: 340$

19. Giordano C, Vizza D, Panza S, Barone I, Bonofiglio D, Lanzino M, Sisci D, De Amicis F, Fuqua SA, Catalano S, Andò S: Leptin increases HER2 protein levels through a STAT3-mediated up-regulation of Hsp90 in breast cancer cells. Mol Oncol 2013, 7:379-391

20. Fiorio E, Mercanti A, Terrasi M, Micciolo R, Remo A, Auriemma A, Molino A, Parolin V, Di Stefano B, Bonetti F, Giordano A, Cetto GL, Surmacz E: Leptin/HER2 crosstalk in breast cancer: in vitro study and preliminary in vivo analysis. BMC Cancer 2008, 8:305

21. Saxena NK, Taliaferro-Smith L, Knight BB, Merlin D, Anania FA, O'Regan RM, Sharma D: Bidirectional crosstalk between leptin and insulin-like growth factor-I signaling promotes invasion and migration of breast cancer cells via transactivation of epidermal growth factor receptor. Cancer Res 2008, 68:9712-9722

22. Soma D, Kitayama J, Yamashita H, Miyato H, Ishikawa M, Nagawa H: Leptin augments proliferation of breast cancer cells via transactivation of HER2. J Surg Res 2008, 149:9-14

23. Catalano S, Mauro L, Marsico S, Giordano C, Rizza P, Rago V, Montanaro D, Maggiolini M, Panno ML, Andó S: Leptin induces, via ERK1/ERK2 signal, functional activation of estrogen receptor alpha in MCF-7 cells. J Biol Chem 2004, 279:19908-19915

24. Giordano C, Chemi F, Panza S, Barone I, Bonofiglio D, Lanzino M, Cordella A, Campana A, Hashim A, Rizza P, Leggio A, Győrffy B, Simões BM, Clarke RB, Weisz A, Catalano S, Andò S: Leptin as a mediator of tumor-stromal interactions promotes breast cancer stem cell activity. Oncotarget 2016, 7:1262-1275

25. Wang T, Fahrmann JF, Lee H, Li YJ, Tripathi SC, Yue C, Zhang C, Lifshitz V, Song J, Yuan Y, Somlo G, Jandial R, Ann D, Hanash S, Jove R, Yu H: JAK/STAT3-regulated fatty acid $\beta$-oxidation is critical for breast cancer stem cell self-renewal and chemoresistance. Cell Metab 2018, 27:136-150

26. Kato S, Abarzua-Catalan L, Trigo C, Delpiano A, Sanhueza C, García K, Ibañez C, Hormazábal K, Diaz D, Brañes J, Castellón E,
Bravo E, Owen G, Cuello MA: Leptin stimulates migration and invasion and maintains cancer stem-like properties in ovarian cancer cells: an explanation for poor outcomes in obese women. Oncotarget 2015, 6:21100-21119

27. Leggio A, Catalano S, De Marco R, Barone I, Andò S, Liguori A: Therapeutic potential of leptin receptor modulators. Eur J Med Chem 2014, 78:97-105

28. Gertler A, Elinav E: Novel superactive leptin antagonists and their potential therapeutic applications. Curr Pharm Des 2014, 20:659-665

29. Gertler A, Solomon G: Leptin-activity blockers: development and potential use in experimental biology and medicine. Can J Physiol Pharmacol 2013, 91:873-882

30. Zhang J, Gong M: Review of the role of leptin in the regulation of male reproductive function. Andrologia 2018, [Epub ahead of print] doi:10.1111/and.12965

31. Kawwass JF, Summer R, Kallen CB: Direct effects of leptin and adiponectin on peripheral reproductive tissues: a critical review. Mol Hum Reprod 2015, 21:617-632

32. Mizuno Y, Gotoh A, Kamidono S, Kitazawa S: Establishment and characterization of a new human testicular germ cell tumor cell line (TCam-2). Nihon Hinyokika Gakkai Zasshi 1993, 84:1211-1218

33. Russell SM, Lechner MG, Mokashi A, Megiel C, Jang JK, Taylor CR, Looijenga LH, French CA, Epstein AL: Establishment and characterization of a new human extragonadal germ cell line, SEM-1, and its comparison with TCam-2 and JKT-1. Urology 2013, 81:464.e1-464.e9

34. de Jong J, Stoop H, Gillis AJ, Hersmus R, van Gurp RJ, van de Geijn GJ, van Drunen E, Beverloo HB, Schneider DT, Sherlock JK, Baeten J, Kitazawa S, van Zoelen EJ, van Roozendaal K, Oosterhuis JW, Looijenga LH: Further characterization of the first seminoma cell line TCam-2. Genes Chromosomes Cancer 2008, 47: 185-196

35. Eckert D, Nettersheim D, Heukamp LC, Kitazawa S, Biermann K, Schorle H: TCam-2 but not JKT-1 cells resemble seminoma in cell culture. Cell Tissue Res 2008, 331:529-538

36. Catalano S, Panza S, Malivindi R, Giordano C, Barone I, Bossi G, Lanzino M, Sirianni R, Mauro L, Sisci D, Bonofiglio D, Andò S: Inhibition of Leydig tumor growth by farnesoid $\mathrm{X}$ receptor activation: the in vitro and in vivo basis for a novel therapeutic strategy. Int J Cancer 2013, 132:2237-2247

37. Sirianni R, Chimento A, Malivindi R, Mazzitelli I, Andò S, Pezzi V: Insulin-like growth factor-I, regulating aromatase expression through steroidogenic factor 1, supports estrogen-dependent tumor Leydig cell proliferation. Cancer Res 2007, 67:8368-8377

38. Catalano S, Malivindi R, Giordano C, Gu G, Panza S, Bonofiglio D, Lanzino M, Sisci D, Panno ML, Andò S: Farnesoid X receptor, through the binding with steroidogenic factor 1-responsive element, inhibits aromatase expression in tumor Leydig cells. J Biol Chem 2010, 285:5581-5593

39. Panza S, Malivindi R, Chemi F, Rago V, Giordano C, Barone I, Bonofiglio D, Gelsomino L, Giordano F, Andò S, Catalano S: Glucocorticoid receptor as a potential target to decrease aromatase expression and inhibit Leydig tumor growth. Am J Pathol 2016, 186: $1328-1339$

40. Di Gioia ML, Leggio A, Liguori A, Perri F: Solid-phase synthesis of N-Nosyl- and N-Fmoc-N-methyl- $\alpha$-amino acids. J Org Chem 2007, 72:3723-3728

41. Giordano C, Barone I, Vircillo V, Panza S, Malivindi R, Gelsomino L, Pellegrino M, Rago V, Mauro L, Lanzino M, Panno ML, Bonofiglio D, Catalano S, Andò S: Activated FXR inhibits leptin signaling and counteracts tumor-promoting activities of cancer-associated fibroblasts in breast malignancy. Sci Rep 2016, 6:21782

42. Catalano S, Leggio A, Barone I, De Marco R, Gelsomino L, Campana A, Malivindi R, Panza S, Giordano C, Liguori A, Bonofiglio D, Liguori A, Andò S: A novel leptin antagonist peptide inhibits breast cancer growth in vitro and in vivo. J Cell Mol Med 2015, 19:1122-1132 
43. Knight BB, Oprea-Ilies GM, Nagalingam A, Yang L, Cohen C, Saxena NK, Sharma D: Survivin upregulation, dependent on leptinEGFR-Notch1 axis, is essential for leptin-induced migration of breast carcinoma cells. Endocr Relat Cancer 2011, 18:413-428

44. Gonzalez-Perez RR, Xu Y, Guo S, Watters A, Zhou W, Leibovich SJ: Leptin upregulates VEGF in breast cancer via canonic and noncanonical signalling pathways and NFkappaB/HIF-1alpha activation. Cell Signal 2010, 22:1350-1362

45. Catalano S, Giordano C, Rizza P, Gu G, Barone I, Bonofiglio D, Giordano F, Malivindi R, Gaccione D, Lanzino M, De Amicis F, Andò S: Evidence that leptin through STAT and CREB signaling enhances cyclin D1 expression and promotes human endometrial cancer proliferation. J Cell Physiol 2009, 218:490-500

46. Catalano S, Marsico S, Giordano C, Mauro L, Rizza P, Panno ML, Andò S: Leptin enhances, via AP-1, expression of aromatase in the MCF-7 cell line. J Biol Chem 2003, 278:28668-28676

47. Park HY, Kwon HM, Lim HJ, Hong BK, Lee JY, Park BE, Jang Y, Cho SY, Kim HS: Potential role of leptin in angiogenesis: leptin induces endothelial cell proliferation and expression of matrix metalloproteinases in vivo and in vitro. Exp Mol Med 2001, 33:95-102

48. Ghasemi A, Hashemy SI, Aghaei M, Panjehpour MJ: Leptin induces matrix metalloproteinase 7 expression to promote ovarian cancer cell invasion by activating ERK and JNK pathways. Cell Biochem 2018, 119:2333-2344

49. Otvos L Jr, Kovalszky I, Riolfi M, Ferla R, Olah J, Sztodola A, Nama K, Molino A, Piubello Q, Wade JD, Surmacz E: Efficacy of a leptin receptor antagonist peptide in a mouse model of triple-negative breast cancer. Eur J Cancer 2011, 47:1578-1584

50. Otvos L Jr, Kovalszky I, Scolaro L, Sztodola A, Olah J, Cassone M, Knappe D, Hoffmann R, Lovas S, Hatfield MP, Beko G, Zhang S, Wade JD, Surmacz E: Peptide-based leptin receptor antagonists for cancer treatment and appetite regulation. Biopolymers 2011, 96:117-125

51. Martins FF, Aguila MB, Mandarim-de-Lacerda CA: Impaired steroidogenesis in the testis of leptin deficient mice (ob/ob -/-). Acta Histochem 2017, 119:508-515

52. Tena-Sempere M, Manna PR, Zhang FP, Pinilla L, González LC, Diéguez C, Huhtaniemi I, Aguilar E: Molecular mechanisms of leptin action in adult rat testis: potential targets for leptin-induced inhibition of steroidogenesis and pattern of leptin receptor messenger ribonucleic acid expression. J Endocrinol 2001, 170:413-423

53. Herrid M, O'Shea T, McFarlane JR: Ontogeny of leptin and its receptor expression in mouse testis during the postnatal period. Mol Reprod Dev 2008, 75:874-880

54. Ishikawa $\mathrm{T}$, Fujioka $\mathrm{H}$, Ishimura $\mathrm{T}$, Takenaka A, Fujisawa M: Expression of leptin and leptin receptor in the testis of fertile and infertile patients. Andrologia 2007, 39:22-27

55. Aquila S, Gentile M, Middea E, Catalano S, Morelli C, Pezzi V, Andò S: Leptin secretion by human ejaculated spermatozoa. J Clin Endocrinol Metab 2005, 90:4753-4761

56. Barone I, Giordano C, Bonofiglio D, Andò S, Catalano S: Leptin, obesity and breast cancer: progress to understanding the molecular connections. Curr Opin Pharmacol 2016, 31:83-89 